\title{
Mathematical Inductive-Creative Reasoning, A Theoretical Study
}

\author{
Robiah Adawiyah \\ Department of Mathematics Education \\ UIN SyarifHidayatullah Jakarta \\ Indonesia \\ biah_hameerch@yahoo.co.id
}

\author{
Abdul Muin \\ Department of Mathematics Education \\ UIN SyarifHidayatullah Jakarta \\ Indonesia \\ muinfasya @gmail.com
}

\author{
Khairunnisa \\ Department of Mathematics Education \\ UIN SyarifHidayatullah Jakarta \\ Indonesia \\ Khairunnisa@uinjkt.ac.id
}

\begin{abstract}
Reasoning is one of ability that should be developed on students' mathematics learning process. Through reasoning students are expected to know that mathematics is not to rote the formulas but to understand, prove and make conclusion. This article discusses about students' mathematical inductive-creative reasoning ability, a mathematical study result from several sources. Inductive reasoning is the process of thinking based on specific data and lead to the general conclusion, while the creative reasoning is based on Lithner's theoretical framework that divides the two reasoning, they are creative reasoning and imitative reasoning. The results of this study formulate three indicators of mathematical inductivecreative reasoning abilities, such as creative generalization, creative analogies, and creative patterns.
\end{abstract}

Keywords-Reasoning, mathematical inductive-creative reasoning, Creative Generalization, Creative Analogies, and Creative Patterns.

\section{INTRODUCTION}

Reasoning is one of ability that must be owned and developed on students' mathematics learning process. National Council of Teachers of Mathematics (NCTM) establishes reasoning ability to be one of the standard mathematical ability that students need to have along with the ability of understanding, problem solving, communication, connections and representation.[13] Reasoning ability is very important for supporting various other mathematical abilities. Students will not be able to solve the problem well without good reasoning ability. Research which is conducted by Kishimoto with the purpose of identifying the influence proportionality reasoning and metacognition in problem solving abilities on multiplication word problems with fractions showed that reasoning ability is more important than metacognition.[20] In addition, the ability of connection, communication, and representation must be supported with good reasoning.[22] The importance of reasoning clearly seen when related to understanding ability, as mathematics understood by mathematical reasoning. The Necessity of reasoning ability is not only in the process of learning mathematics, but also in everyday life. Small children, who do not know the heat of the fire, would dare to touch the fire, after the experience of that fire is hot, then the child will not dare to touch fire again. It shows a process of reasoning in child cognition. Starting when children try to touch the fire then based on experience that touch fire is hot then inference process is formed that all the fire is hot, so that children will not touch the fire again. Accordingly, reasoning ability leads to the conclusion making which is critical in many aspect of life.

\section{A. Definition of Mathematical Reasoning}

In general terms, reasoning can be defined as the process of drawing conclusions based on evidence.[22] Another definition of the reasoning expressed by Johnson-laird[2] and Byrne stated that the reasoning is the process of drawing conclusions based principles and facts which someone draw new conclusions or evaluating conclusions that were known. From the above opinion we can say that reasoning is the thinking process that led to the conclusion based on the principles or facts.

There are two types of reasoning based on the ways to draw conclusions; deductive reasoning and inductive reasoning. This article focuses on the discussion of inductive reasoning. Inductive reasoning illustrates the process of reasoning based on specific premises then general conclusions 
drawn[2].Polya[6] defines inductive reasoning as a natural reasoning that allows someone to gain scientific knowledge, while Neubert and Binko found inductive reasoning relates to discover patterns and pictures. Another opinion, Hume[9] stated that inductive reasoning is an activity of mind to conclude based on something that is observed to unobserved, see the sunrise every day will lead to the conclusion that tomorrow the sun will rise again. Referring to the various opinions on the statement above, inductive reasoning is the kind of reasoning that starts from the specific facts and lead to the general conclusion.

Some of reasoning that included in inductive reasoning such as generalization, analogy, and patterns. Polya[6] defines generalization as a process through consideration of the set of objects given to a larger set that contains the given one. According to Haylock's[3] opinion, generalization is characteristic of mathematical reasoning, generalization is a process to recognize what will occur in all the particulars of the object or mathematical relationship. Furthermore Soekadijo[14] defines generalization as a reasoning to draw general conclusions from premises in the form of empirical propositions. While Sumarmo[21] said generalization as a general conclusion based on the number of observed data. Another definition of generalization was an argument with the conclusion that a many things is based on some of the things observed.[16]

Polya[6] defines Analogy as a kind of similarity, similar objects will be similar in some aspects. In line with Polya, Holyoak[9] also argues that the analogy is a kind of similarity, the two situations is said to be analogous or similar if they share a pattern of relationships between the elements even though the elements of the two situations are different. English[11] argues, the analogy is the ability to reason with correspond patterns. While Soekadijo[14], interpreted about the analogy relates to compare two different things, but just pay attention to the similarities without notice the difference. Sumarmo[21] stated that the analogy is drawing conclusions based on the similarity of the process or data.

Pattern is one kind of reasoning that are suggested, as quoted by the NCTM, in the middle class students should have frequent and diverse experiences with mathematics reasoning such as examine patterns and structures to detect regularity.[13] Further more Sumarmo[21] describe patterns as to use patterns of relationships to analyze the situation.

Based on the description above, this article will be limited to the following:

1. Generalization is the process of drawing conclusions based on a number of the observed data

2. Analogy is withdrawal similarity of a number of processes or data

3. Patterns, to use a pattern of relationships to analyze the situation

\section{B. Mathematical Creative Reasoning}

Mathematical Creative reasoning in this article refers to Lithner's theoretical framework. Lithner [7] defines reasoning as the process of adopting ways of thinking to make an assertion and reach conclusions in a problem-solving.

Based on the nature, Lithner divides reasoning into two types, creative reasoning and imitative reasoning. Imitative Reasoning is the process of reasoning which the way of reason based by imitating or remembering. Furthermore Lithner [7] divides imitative reasoning into two types, memory reasoning and algorithmic reasoning.

According to Lithner, memory reasoning fulfills the following criteria:[7]

1. The strategy choice to solve the problem just remembering a complete answer

2. Implementation of the strategy in solving the problem simply by writing an answer, because the answer is already in mind.

While algorithmic reasoning fulfills following criteria:[7]

1. The strategy choice to solve the problem just remembering a solution algorithm.

2. The part of reasoning remains of the implementation of the strategy is the easy part of the reasoning, only a careless mistake that makes reasoner can't reach to the conclusion.

From the above criteria, we can say that questions which only require students to recall answer, procedures or algorithm does not practice creative reasoning but imitative reasoning.

According to Lithner, mathematical creative reasoning or in Lithner's terms as creative mathematically founded reasoning (CMR), fulfills the following criteria:[8]

\section{Creativity}

Reasoner creates a new reasoning sequence with considering aspect of fluent and flexible. Creative in this case emphasizes the originality aspect of the students' answers.

2. Plausibility.

There are arguments which can explain the strategy choice why the conclusions are true.

\section{Anchoring}

Anchoring means that the arguments are based on the intrinsic mathematical properties that involve reasoning.

The criteria of creativity in point one refers to creative reasoning, while the criteria of plausibility and anchoring in point two and three refers to mathematical reasoning, so that a reasoning is said creative mathematically founded reasoning (CMR) must fulfills three criteria such as creativity, plausibility and anchoring.

\section{Creative Thinking}

In this section, the discussion talks about creative thinking. According to Supriadi [23] creativity is an ability to produce something new, whether it will be the idea or the real work that different from the existing. While Semiawan [23] stated that creativity is the ability to reveal new ideas then applied in the problem solving. Urban [1] defines creativity such a new creation, unusual and surprising as the solution of perceived problems. Furthermore according to Bergstrom [5] Creativity 
is an individual's ability to produce Something New and unpredictable. Based on the opinion of some experts formulate creativity with reference to something that is new or unusual. Broader definition of creativity expressed by Munandar [18] that creativity is a skill that reflects the fluency, flexibility, originality in thinking, and the ability to elaborate the idea.

Creative thinking can be interpreted as the thought process that produces new things, it can be new relationships of various things, a new solution of a problem, a new artistic form and so on [19]. Creative thinking involves attention that focused on the development process and keeping the mind so as to take advantage of something unexpected [15]. Mednick [15] defines creative thinking as the formation of the elements connected into a new combination. Other opinions Puccio and Murdock [12] argued that creative thinking contains cognitive skills and metacognitive, generate many ideas, different ideas, new ideas, include the disposition of such an open attitude, brave, act quickly, beliefs that something is part of a whole, using other people's way of thinking that is critical, and their sensitivity to the feelings of others. Furthermore Nickerson[17] argues creative thinking is expansive, innovative, unconstrained thinking, creative thinking relate to exploration and generate ideas and include bold characteristics, uninhibited, fantastic, imaginative, free spirit, unpredictable, and revolutionary.

Creative thinking in mathematics can be interpreted as solving the problem or mathematical tasks involving creative thinking process. Spraker [4] defines mathematical creativity as the ability to generate new solution or unusual from mathematical tasks. Furthermore creative thinking in mathematics can be regarded as an orientation in which such math instruction includes problem solving and discovery [12] Tall [12] said that mathematical creative thinking is person's ability in problem solving or development thinking by observing the rules of deductive reasoning and relationships of concepts that generated to be integrated on the main points of mathematics. Based on theory of creativity and creative thinking we can conclude that mathematical creative thinking is the ability to solve mathematical problems which includes originality, flexibility, fluency and elaboration.

Munandar provide description of the characteristics of creative thinking abilities of students as follows:[18]

1) fluency

- reveal many answers, ideas, questions or solutions

- suggest many ways of doing things thinking about more than one answer

2) Flexibility

- reveal various answer, ideas, or questions

- being able to look the problem more than one view

- finding many alternatives being able to change the approach or way of thinking

3) Originality

- reveal unique idea

- thinking different way from the usual or unusual in expressing themselves
- generate different combination from the usual or unusual of parts or element

4) Elaboration

- being able to develop or enrich an idea or product

- elaborate in detail of an idea, object, and situation that seems more interesting

5) Evaluation

- being able to determine of own assessment standard

- being able to make decision in open situation

- not only reveal the idea but also make it happen in realistic

In this section, the discussion focuses on one of the indicators of creative thinking that is originality. Munandar[18] provide descriptions of originality as follows: reveal new and unique expressions or ideas, thinking different way from the usual or unusual in expressing themselves, generate different combination from the usual or unusual of parts or element.

The other says original is something that was first created [10]. In addition to assessing the response of creativity is usually evaluated in a measurement, originality judged from the infrequency response statistical significance.[4] In this article originality in question is the ability of students to solve problems in ways that are unique or unusual.

\section{Mathematical Inductive-Creative Reasoning}

In general terms, there are two types of reasoning namely deductive reasoning and inductive reasoning. The discussion focuses on inductive reasoning. Definition of Inductive Reasoning in this article is process of thinking based on specific data and lead to general conclusion. Furthermore, inductive reasoning in this discussion limited to generalization, analogy, and pattern.

Based on the explanation about generalization, analogy ad pattern, this article will be limited to the following:

1. Generalization is the process of drawing conclusions based on a number of the observed data

2. Analogy is withdrawal similarity of a number of processes or data

3. Patterns, to use a pattern of relationships to analyze the situation

We had already known that there are deductive reasoning and inductive reasoning, but according to Lithner's theoretical framework, there are two types of reasoning, creative and Imitative reasoning. Lithner defines creative reasoning or creative mathematically founded reasoning (CMR) fulfill three criteria such as creativity, plausibility and anchoring. Creativity means that the reasoner creates a new reasoning sequence with considering aspect of fluent and flexible and creative in this case emphasizes the originality aspect of the students' answers. While Plausibility means there are arguments which can explain the strategy choice why the conclusions are true. Anchoring means that the arguments are 
based on the intrinsic mathematical properties that involve reasoning.

Refer to Lithner's theoretical framework, creative reasoning in this article means reasoning ability that involving creativity's criteria. From the theories of creative thinking above, creativity reflects the fluency, flexibility, originality, elaboration and so on. Therefore, criteria of creativity in this discussion related to originality aspect. In previous discussion, we had already discussed that originality in this article means students' ability to solve problem in unique way or unusual.

Based on the explanation about creative reasoning and creativity, this article will be limited to the following:

1. Creative reasoning means reasoning ability that involving creativity criteria

2. Criteria of creativity related to originality

3. Originality means student's ability to solve problem in unique way or unusual

Now, we defines Mathematical Inductive-creative reasoning as process of thinking based on the specific data and lead to general conclusion in a unique way.

In this section formulate the indicators of mathematical inductive-creative reasoning based on the theories about the ability of mathematical reasoning and mathematical creative reasoning. In this article the indicators of inductive reasoning are generalization, analogy, and using relationship of patterns to analyze the situation, while the creative criteria refer to Lithner's theoretical framework that emphasizes originality. Therefore, the indicator of mathematical inductive-creative reasoning in this study are:

1) Drawing conclusions based on a number of the observed data in a unique way (creative generalization).

2) Drawing similarity of process or data in a unique way (creative analogy).

3) Using a corelation of pattern to analyze the situation in a unique way (creative patterns).

\section{E. Example Item of Mathematical Inductive-Creative Reasoning Ability}

Based on the indicators of Mathematical inductive-creative reasoning ability, the following is an item related to indicator of creative generalization.

The architecture draw a housing sketch, consists of rectangular and square. Rectangle of $\mathrm{ABCD}$ sized $\mathrm{AB}=4 \mathrm{~cm}$, $\mathrm{AD}=3 \mathrm{~cm}$. Square of $\mathrm{BEFG}$ sized $\mathrm{BE}=\mathrm{EF}=6 \mathrm{~cm}, \mathrm{AH}=1$ $\mathrm{cm}, \mathrm{IF}=2 \mathrm{~cm}, \mathrm{GJ}=3 \mathrm{~cm}$. The shaded area HBIJ will be used as a park. Each one $\mathrm{cm} 2$ at the park takes one bunch of grass. What can you conclude about the amount of grass needed if the model is enlarged $\mathrm{n}$ times?

\section{RESULTS}

The results of this study were provided definition of mathematical inductive-creative reasoning, the definition is derived from the theories of reasoning that has been discussed in the theoretical study, further more the result of this study also provides a definition of the indicators included in mathematical inductive-creative reasoning

In this article, Mathematical Inductive-Creative Reasoning is the process of thinking based on the specific data and lead to general conclusion in a unique way.

Based on the discussion of theoretical study that limit inductive reasoning only on generalization, analogy and patterns, so that the indicators of mathematical inductivecreative in this study are:

1. Drawing conclusions based on a number of the observed data in a unique way (creative generalization)

2. Drawing similarity of process or data in a unique way (creative analogy).

3. Using a corelation of pattern to analyze the situation in a unique way (creative patterns).

\section{CONCLUSION}

Generally there are two types of reasoning based on drawing the conclusion; deductive reasoning and inductive reasoning. These reasoning such as generalizations, analogy and pattern related to inductive reasoning. According to Lithner's theoretical framework, reasoning divides into two types, namely creative reasoning and imitative reasoning. Creative reasoning or creative mathematically founded reasoning (CMR) fulfills three criteria such as creativity, plausibility, and anchoring. According to the theories of mathematical reasoning, mathematical creative reasoning and creative thinking. This study defines Mathematical InductiveCreative Reasoning as process of thinking based on the specific data and lead to general conclusion in a unique way. Furthermore, we provide the indicators which include of mathematical inductive-creative reasoning. Indicators of mathematical inductive-creative reasoning in this study are creative generalizations, analogies creatives, and creative patterns. We define creative generalization as drawing conclusions based on a number of the observed data in a unique way, while creative analogy is defined as drawing similarity of process or data in a unique way, and creative patterns is defined as using a relationships of pattern to analyze the situation in a unique way.

\section{References}

[1] A.Tan, Creativity a Handbook for Teachers, Singapore: World Scientific Publishing Co. Pte. Ltd, 2007.

[2] C. Christou and E. Papageorgiu, A framework of Mathematics Inductive Reasoning, Learning and Instruction, Vol. 17, 2007, pp. 55-66.

[3] D. Haylock, F. Thangata, Key Concepts in Teaching Primary Mathematics, London: SAGE publication, 2007.

[4] D. W. Haylock, A Framework for Assessing Mathematical Creativity in School Children, educational studies in mathematics, Vol. 18, 1987, pp. 59-74.

[5] E. Pehkonen, The State of Art in Mathematical Creativity, ZDM, 1997. 
[6] G. Polya, Mathematics and Plausible Reasoning vol. I Induction and Analogy in Mathematics, New Jersey: Princeton University Press, 1954.

[7] J. Lithner, A research framework for creative and imitative reasoning, Educational Studies in Mathematics, 2008, pp. 255-276.

[8] J. Lithner, Learning Mathematics by Creative or Imitative Reasoning, $12^{\text {th }}$ International Congress on Mathematical Education, 2012.

[9] K. J. Holyoak, The Cambridge Handbook of Thinking and Reasoning, New York: Cambridge University Press, 2005.

[10] K. S. Meador, Creative Thinking and Problem Solving for Young Learners, Colorado: Teacher Ideas Press, 1997.

[11] L.D. English, Mathematical and Analogical Reasoning of Young Learner, New Jersey: Lawrence Erlbaum Associates, 2004.

[12] L. Moma, "Menumbuhkan Kemampuan Berpikir Kreatif Matematis Melalui Pembelajaran Generatif Siswa SMP", Prosiding Seminar Nasional Pendidikan Matematika FMIPA UNY, Yogyakarta, 2012, h. 506.

[13] Principles and Standards for School mathematics, Reston: NCTM, 2000.

[14] R. G. Soekadijo, Logika Dasar (tradisional, simbolik, dan induktif), Jakarta: PT Gramedia Pustaka Utama, 1993.

[15] R.K. Sawyer et al, Creativity and Development, New York: Oxford University Press, 2003.

[16] R. M. Johnson, A Logic Book Fundamentals of Reasoning, Belmont, CA: Thomson Higher Education, 2007.

[17] R.S Nickerson, Enhancing Creativity, in R.J Stenberg, Ed. Handbook of Creativity, New York: Cambridge University Press, 1999.

[18] S. C. U Munandar, Mengembangkan Bakat dan Kreativitas Anak Sekolah, Jakarta: PT Gramedia Widiasarana Indonesia, 1992.

[19] S. W. Sarwono, Pengantar Umum Psikologi, Jakarta: PT Bulan Bintang, 2000

[20] T. Kishimoto, "Solving Multiplicative Word Problems with Decimal Fractions: The Effects of Proportional Reasoning ad Metacognition", Proceedings of the conference of the international Group for the Psychology of Mathematics Education (PME), volume 3, 2000

[21] U. Sumarmo dan H. Hendriana, penilaian pembelajaran matematika, Bandung: Refika Aditama, 2014.

[22] W. G. Martin, Focus in High School Mathematics: Reasoning and Sense Making, Reston: NCTM, 2009.

[23] Y. Rachmawati dan E. Kurniati, Strategi Pengembangan Kreativitas pada Anak Usia Taman Kanak - Kanak, Jakarta: Kencana Prenada Media Group, 2010 